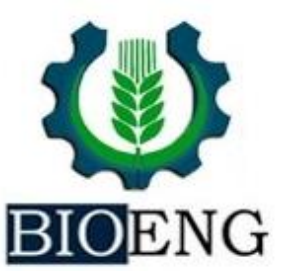

\title{
THERMAL COMFORT IN INDIVIDUAL SHELTERS FOR CALVES WITH NON-CONVENTIONAL CEILING MADE OF AGRO-INDUSTRIALBY-PRODUCTS
}

\section{S. L. de Castro Júnior*; D. C. G. de Oliveira; F. L. Caneppele; J. Fiorelli}

USP- Universidade de São Paulo, Faculdade de Zootecnia e Engenharia de Alimentos, Pirassununga, SP, Brasil

Article history: Received 25 September 2017; Received in revised form 24 October 2017; Accepted 26 October 2017; Available online 27 December 2017.

\begin{abstract}
This study evaluated the thermal comfort conditions in two individuals calve shelter models covered with fiber cement tile without ceiling and using a ceiling made of low density particleboards from agro-industrial by-products (40\% sugarcane bagasse and 60\% Pinus sp. shavings) bonded with polyurethane bi-component resin based on castor oil. In the ambience study, dry bulb temperature (DBT), black globe temperature (BGT) and relative humidity $(\mathrm{RH})$ of the calf hutches were evaluated. Indices, such as Black Globe Temperature and Humidity Index (BGHI) and Radiant Thermal Load (RTL), and also thermographic images of the internal surface of the shelters were studied. The use of fuzzy modeling has been proposed, allowing the comparison of the BGT, BGHI and RTL indices, and via these values, attributing the comfort situation, thus seeking to optimize the experimental evaluations. The results indicate that the presence of the ceiling did not contribute to a heat level reduction inside the shelters, which presented above the comfort conditions for the animals during the summer. Through observation, there was a reduction of the internal temperature of the surfaces of the shelter with a ceiling.
\end{abstract}

Keywords: sugarcane bagasse; Pinus sp. shavings; rural construction; thermal comfort.

\section{CONFORTO TÉRMICO EM ABRIGO INDIVIDUAL PARA BEZERROS COM FORRO NÃO CONVENCIONAL DE SUBPRODUTOS AGROINDUSTRIAIS}

\section{RESUMO}

Este trabalho avaliou as condições de conforto térmico em dois modelos de instalações individuais para bezerros cobertos com telha de fibrocimento sem forro e com forro de chapas de partículas de baixa densidade de subprodutos agroindustriais ( $40 \%$ de bagaço de cana-de-açúcar e $60 \%$ de maravalha de Pinus sp.) aglutinados com resina poliuretana bicomponente à base de óleo de mamona. No estudo da ambiência, foram avaliadas a temperatura ambiente (TBS), a temperatura de globo negro (TGN) e a umidade relativa (UR) nas instalações. Foram comparados os Índices de Temperatura de Globo e Umidade (ITGU) e Carga Térmica Radiante (CTR), além de imagens termográficas das superfícies internas dos abrigos. Também foi proposta a utilização da modelagem fuzzy, permitindo a comparação dos valores de ITGU, TGN e CTR e atribuição, mediante os valores desses índices, a situação de conforto, buscando assim otimizar as avaliações experimentais. Os resultados indicam que a presença do forro não contribuiu com a redução dos índices térmicos, que se mostraram acima das condições de conforto para os animais durante o

sergio.castro@usp.br 
verão, apesar de ser observado uma redução nas temperaturas internas das superfícies do abrigo com forro.

Palavras-chave: bagaço de cana; maravalha de Pinus sp.; construção rural; conforto térmico.

\section{INTRODUCTION}

Calves occupy a stage under intense attention within cattle and milk production. This is due to the fact that these animals constitute the first evolutionary stage of the herd, a delicate phase in which calves are subject to various factors that may be negative for their performance, such as inadequate facilities, poor postpartum care and hygiene. Any problem at this stage will cause delays and loss throughout the production chain.

As an aggravating factor, Brazilian climatic conditions - where high temperatures are frequently reached during much of the year - can cause thermal stress in the animals, which are often from European regions (BARNABÉ et al. 2014).

In this context, shelters for calves must offer conditions for good hygiene and welfare and may be constructed using different kind of materials, such as bamboo, wood and roofing tiles of several geometries and compositions (FERREIRA, 2005). In order to ensure improvements in thermal comfort, these facilities commonly called calf hutches or calf shelters - should also be structured to minimize temperature fluctuations, reduce internal relative humidity and promote air ventilation without allowing the occurrence of cold air streams (KAWABATA, 2005).

In recent years, several studies have been focusing on the incorporation of nonconventional materials in rural constructions, either to add some value to these materials and/or to improve constructive features of the facilities (BARNABÉ et al., 2015; BARBIRATO et al., 2015, DA SILVA et al., 2015). Some of these materials include sugarcane bagasse, a residue from sugarcane processing; shavings of Pinus sp., waste from the furniture industry; and polyurethane bi-component resin based on castor oil, a bender that does not emit formaldehyde during its production (CASTRO JUNIOR et al. 2014).

However, according to Vasconcelos et al. (2009), there is still little scientific information about confection and thermal efficiency of calf hutches, although they are widely used in Brazilian cattle breeding.

One way to assess the thermal efficiency of rural facilities is by determining parameters that influence animal comfort. Considering these parameters, the interactions among air temperature, relative humidity, wind speed and radiation stand out (DIKMEN \& HANSEN, 2009). As such, among the commonly used indices and evaluative parameters there are the black globe temperature, which suggests the combined effects of convection, radiation and its influence on living organisms (BEDFORD \& WARNER, 1934); BGHI (Black Globe Temperature and Humidity Index), which is an index of comfort based of the previous parameter and the RTL (Radiant Thermal Load), which is defined as the total radiation received by a body in a certain surrounding space (BOND \& KELLY, 1995).

Shaw \& Simões (2007) observed the importance of certain indices in estimating parameters that aid in decision making. It is also noted that the technological means, especially computer systems, do not have the aptitude to deal with situations that are common for the human beings, as the determination of comfort situations. Thus, the use of fuzzy logic, proposed by Lotfi A. Zadeh in 1965 can enter to meet this need (ZADEH, 1965).

This work has the objective of applying a ceiling, composed of agro- 
industrial by-products such as sugarcane bagasse and Pinus sp. shavings, in installations for calves, with the purpose of

\section{MATERIAL AND METHODS}

The study was conducted in the municipality of Pirassununga - SP, in the dairy cattle sector of the Fernando Costa Campus (University of São Paulo). The city is located at coordinates $21^{\circ} 57^{\prime} 02^{\prime \prime}$ South latitude and $47^{\circ} 27^{\prime} 50^{\prime \prime}$ West longitude and at an altitude of $630 \mathrm{~m}$. The climate is characterized as tropical and seasonal, with rainy summers and dry winters.

\section{Ceiling production}

For the preparation of the ceiling, 5 particleboard panels, $550 \times 550 \times 20 \mathrm{~mm}$, were processed, according to methodology presented by Castro Júnior et al. (2014). The panels, with an average density of 500 $\mathrm{kg} / \mathrm{m}^{3}$ - low density - consist of $40 \%$ sugarcane bagasse (in the shape of fiber) and $60 \%$ Pinus $s p$. residue (in the shape of shavings). As binder material (15\% of the dry weight of the panel) of polyurethane bi-component resin based on castor oil was proposed.

\section{Characterization of the shelters}

The illustrative design of the shelters is shown in Figure 2 ( $a$ and $b$ ) with their respective dimensions. The useful volume $\left(2.13 \mathrm{~m}^{3}\right)$ of the facilities is sufficient to house a standing calf and allow its movement. Both models were arranged side by side, with about $1 \mathrm{~m}$ distance between them, in an area without shade interference, that is, subjected to direct solar radiation all day. Both individual shelters evaluated had wooden side closures (thickness of $0,03 \mathrm{~m}$ ), fiber cement tile roof (thickness of $0,02 \mathrm{~m}$ ) lined with particleboard as a ceiling (B1) and an unlined fiber cement roof tile (B2). In order to guarantee a better quality in the thermal comfort analyzes, the data collection occurred on critical days for calves, i.e., summer days, with high temperature, not rainy and not cloudy. The evaluating the performance of this structure from thermal comfort indexes perspectives.

data collection was conducted in January and February, in which the average temperature was $26.36^{\circ} \mathrm{C}+/-2.08^{\circ} \mathrm{C}$ and average relative humidity $73.94 \%+/-$ $10.31 \%$ during the day and average temperature and relative humidity of $20.74^{\circ} \mathrm{C}+/-1.95^{\circ} \mathrm{C}$ and $89.38 \%+/-$ $14.84 \%$, respectively, overnight at the experiment site.

\section{Thermal performance test}

During the period analyzed, 21 critical days were selected and the collections were carried out at 8:00 a.m., 11:00 a.m., 2:00 p.m. and 5:00 p.m. The values of dry bulb temperature (DBT), black globe temperature (BGT), dew point temperature, relative humidity $(\mathrm{RH})$ and wind speed, all within the installation, were collected using HOBO data loggers, black globes and anemometer. Black Globe Temperature and Humidity Index (BGHI) and Radiant Thermal Load (RTL) comfort indices were determined from the data collected.

The analysis of the temperatures of the internal surfaces ( 9 points in the ceiling in $\mathrm{B} 1$ and in the fiber cement roof in B2) of the installations were also carried out through the thermal camera Thermovisor FLUKE, model ti20 thermal imager, at 2:00 p.m.

The indices were evaluated by descriptive statistics and as a measure of central tendency the arithmetic mean and as a measure of dispersion, the standard deviation was adopted. Inferential analysis was also performed to diagnose the existence of a significant difference between the treatments studied. A completely randomized design (CRD) was used and the data compared by the multiple comparison test (Tukey) when ANOVA was significant, both tested at $p<0.05$. The results were submitted to the treatment through the statistical analysis system 
SISVAR 5.3.

\section{Study by Fuzzy Logic}

Shaw \& Simões (2007) place fuzzy logic, also known as diffuse, nebulous or non- formal logic, as an important decision-making tool when applying its logic to situations common to human reasoning. Considering the development of a system consisting of fuzzy rules, it was primarily important to designate an input processor (also known as a fuzzifier), as well as to identify a set of linguistic rules, a fuzzy inference model and, finally, an output processor called defuzzifier (GABRIEL FILHO et al., 2011). The MATLAB ${ }^{\circledR}$ software and the Fuzzy
Logical Toolbox tool were used in the construction of the fuzzy system. The Mamdani method was used and defuzzification was performed by the center of the area. The pertinence functions of the input variables (BGHI, BGT, RTL) and the output variable (Comfort Situation: Comfort, Alert and Emergency) were elaborated from the data collections, upon characterizing the shelters (Figure 1). Both the input variables and the output variable were represented by trapezoidal pertinence functions combined with triangles, a model also adopted by Gabriel Filho et al. (2011) and Caneppele et al. (2013). The outputs of the fuzzy inference system were presented via the fuzzy rules utilized.

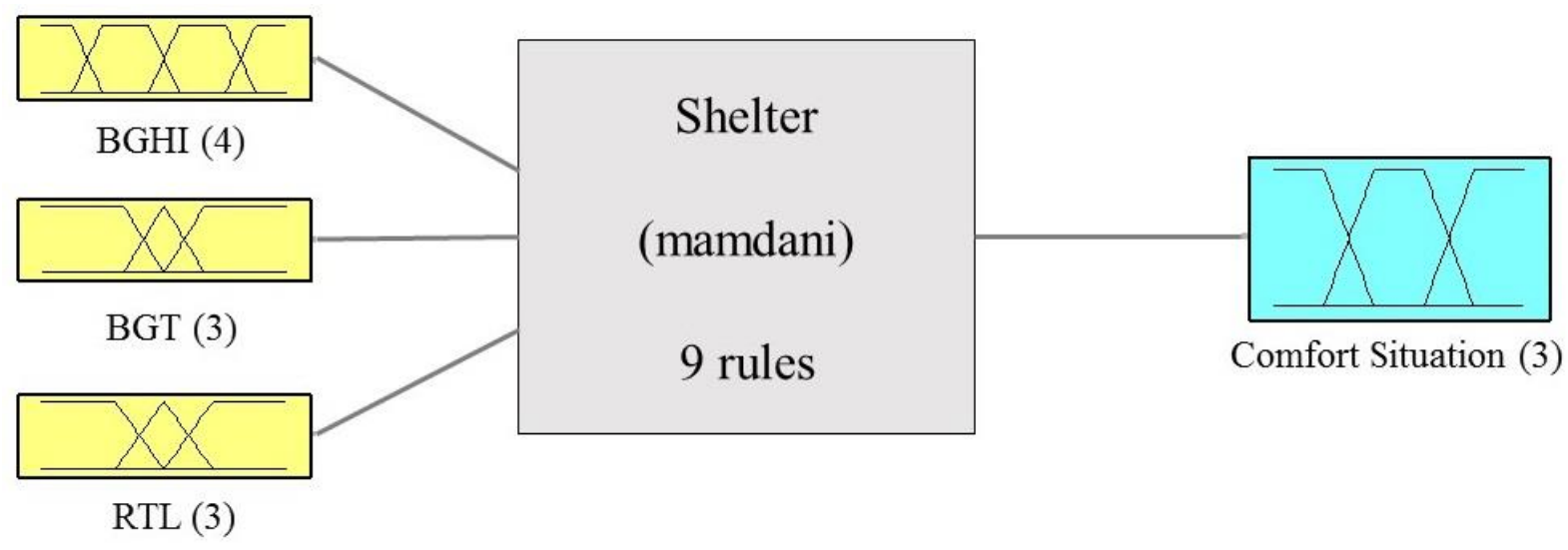

Figure 1. Summary of the fuzzy analysis system

\section{RESULTS AND DISCUSSION}

\section{Analysis of experimental comfort indices}

Table 1 presents mean values and inferential statistical analysis for the variables DBT, RH and BGT and thermal comfort indices BGHI and RTL, at different times.

Analyzing the ambient temperature (DBT) behavior during the day, it was observed that average values established peaks around 11 a.m. and 2 p.m, following the same pattern found by Kawabata et al. (2005), Barnabé et al. (2014) and Cabral et al. (2017) in their studies using calves' facilities. There was no statistical difference of dry bulb temperatures (5\% of significance) between the installation with ceiling (B1) and without that structural element (B2).

The thermoneutrality interval for calves - where it is in its optimum comfort region - ranges from $18^{\circ}$ to $21^{\circ} \mathrm{C}$. In turn, the lower critical effective temperature corresponds to $10^{\circ} \mathrm{C}$, while the upper critical effective temperature is around $26^{\circ} \mathrm{C}$ (CURTIS, 1983). Using this evaluation parameter, both treatments offered a situation above the comfort zone at around 8 a.m. In the other periods, the comfort situation extrapolated the effective upper critical temperature, evidencing the unfavorable thermal situation for calves exposed to hot climates, as in the Brazilian summer.

The relative humidity, in turn, decreased for the two treatments throughout the day, with most critical value collected at 2 p.m., concomitant with 
the increase in temperature - a characteristic quite observed in the literature (KAWABATA et al., 2005). There was also no statistical difference ( $\mathrm{p}>$ 0.05 ) between the treatments for any time for that variable.

The behavior of means values of
BGHI for shelters B1 and B2 varied throughout the day also according to studies carried out by Cabral et al. (2017) and Kawabata et al (2005). No significant difference ( $p>0.05)$ was observed for the BGHI evaluated in Shelters B1 and B2 at the same time.

Table 1. Mean values and respective standard deviations of TBS, UR, TGN, BGHI and RTL for all treatments (B1: with ceiling; B2: without ceiling).

\begin{tabular}{ccccccc}
\hline Time & Treat. & $\begin{array}{c}\text { DBT } \\
\left({ }^{\mathbf{o}} \mathbf{C}\right)\end{array}$ & $\begin{array}{c}\text { UR } \\
(\boldsymbol{\%})\end{array}$ & $\begin{array}{c}\text { BGT } \\
\left({ }^{\mathbf{o}} \mathbf{C}\right)\end{array}$ & BGHI & RTL \\
\hline \multirow{2}{*}{ 8a.m. } & B1 & $23.99^{\mathrm{a}} \pm 2.07$ & $78.99^{\mathrm{a}} \pm 6.89$ & $32.96^{\mathrm{a}} \pm 6.65$ & $81.83^{\mathrm{a}} \pm 6.79$ & $499.46^{\mathrm{a}} \pm 40.90$ \\
& B2 & $23.13^{\mathrm{a}} \pm 2.17$ & $85.52^{\mathrm{a}} \pm 9.20$ & $29.39^{\mathrm{a}} \pm 6.58$ & $78.25^{\mathrm{a}} \pm 6.64$ & $475.77^{\mathrm{a}} \pm 41.47$ \\
\hline \multirow{2}{*}{ 11a.m. } & B1 & $31.26^{\mathrm{a}} \pm 2.29$ & $55.33^{\mathrm{a}} \pm 5.65$ & $32.77^{\mathrm{a}} \pm 3.79$ & $82.20^{\mathrm{a}} \pm 4.07$ & $536.73^{\mathrm{a}} \pm 41.97$ \\
& B2 & $32.99^{\mathrm{a}} \pm 2.48$ & $50.49^{\mathrm{a}} \pm 6.73$ & $33.81^{\mathrm{a}} \pm 6.30$ & $83.32^{\mathrm{a}} \pm 6.28$ & $506.98^{\mathrm{a}} \pm 90.39$ \\
\hline \multirow{2}{*}{ 2p.m. } & B1 & $33.77^{\mathrm{a}} \pm 1.48$ & $45.80^{\mathrm{a}} \pm 4.46$ & $35.10^{\mathrm{a}} \pm 2.89$ & $84.52^{\mathrm{a}} \pm 2.87$ & $528.80^{\mathrm{a}} \pm 26.06$ \\
& B2 & $32.17^{\mathrm{a}} \pm 1.19$ & $44.17^{\mathrm{a}} \pm 3.33$ & $34.27^{\mathrm{a}} \pm 5.74$ & $83.72^{\mathrm{a}} \pm 5.84$ & $467.14^{\mathrm{a}} \pm 92.06$ \\
\hline \multirow{2}{*}{ 5p.m. } & B1 & $31.02^{\mathrm{a}} \pm 1.41$ & $47.95^{\mathrm{a}} \pm 4.67$ & $32.96^{\mathrm{a}} \pm 3.63$ & $82.06^{\mathrm{a}} \pm 3.76$ & $503.44^{\mathrm{a}} \pm 28.05$ \\
& B2 & $29.11^{\mathrm{a}} \pm 1.82$ & $48.64^{\mathrm{a}} \pm 5.91$ & $30.94^{\mathrm{a}} \pm 4.90$ & $79.73^{\mathrm{a}} \pm 4.52$ & $490.71^{\mathrm{a}} \pm 62.85$ \\
\hline
\end{tabular}

Mean values followed by the same letter, in the same column and at the same time, do not differ among themselves by the Tukey test at $5 \%$ probability.

Considering the analyzes performed by Baêta (1985), which correlated BGHI values with the thermal comfort of dairy cattle - and applied in studies carried out by Cabral et al. (2017) and Campos et al. (2005) - BGHI values below 74 define a comfort situation. From 74 to 78 the situation is one of alert. From 79 to 84 , there is a danger situation and above 84 , a degree of emergency is declared. Thus, the treatments ranged from danger to emergency during the day, in a more critical situation in $\mathrm{B} 1$, although this is statistically similar to the other treatment. Thus, none of the evaluated facilities presented adequate thermal comfort levels for calves during the analysis period (summer).

Furthermore, since the black globe temperature is one of the parameters that gives rise to the BGHI, it is possible to observe the same behavior between these indices. The BGT values for the calf hutch were 32.77 to 35.10 , with an amplitude of 2.33. For the unlined installation, no ceiling, this amplitude increased to 4.88 (29.39 to 34.27). The overall mean for B1 was 33.44 and for B2 it was 32.10. As occurred in BGHI, there was no significant difference indicated by the statistical test.

In relation to RTL, it is possible to observe a behavior of these average values during the day that approaches the other indexes evaluated. Furtado et al. (2003) studied RTL behavior, and noted that due to the position of the sun being perpendicular to the horizontal plane in an analyzed site near 12:00 a.m. (which solar radiation reaches its highest values) the highest RTL values of the day will also occur near this time. Again, no significant statistical difference was founded between treatments.

\section{Thermal imaging analysis}

Figure 2 (c and d) presents the results obtained via the temperature gradient on the inner surfaces of the roof (B2) and also the ceiling (B1). It is noteworthy that the increase in temperature accompanies the color scale that ranges from blue tones (cooler) to red tones (warmer).

The shelter with ceiling (B1) presents average surface temperature values approximately $10^{\circ} \mathrm{C}$ lower when compared to the shelter without ceiling B2. By means of these images it is possible to observe that the temperature range in 
shelter B2 is superior when compared to shelter B1: for B1, the temperature gradient is $5.2^{\circ} \mathrm{C}$, much lower than $\mathrm{B} 2$ $\left(12.4^{\circ} \mathrm{C}\right)$. It is noted as well that the maximum temperature found in the ceiling $\left(33.9{ }^{\circ} \mathrm{C}\right)$ in lower than the minimum temperature found in the roof of B2 (34.0 C). In addition, the temperature variation in the ceiling surface of B1 is more homogeneous, without great variations, when compared to the temperatures of the

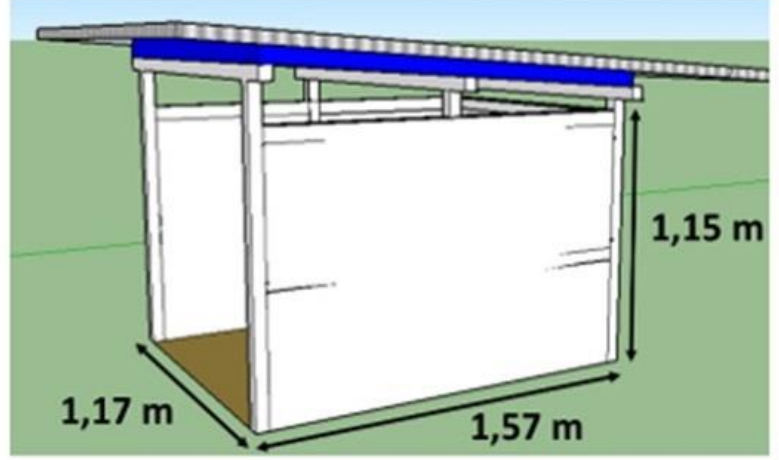

(a)

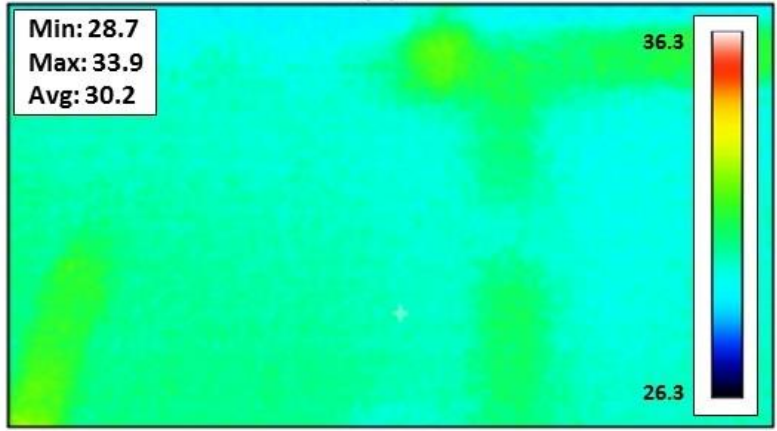

(c) underside of the covering in B2.

The behavior and distribution of the temperature of the ceiling shows its efficiency as a low density insulating material by barring much of the thermal energy from the cover. However, in the shelter model used in this study, that constructive element was not able to generate satisfactory results in decreasing temperature and comfort indexes.

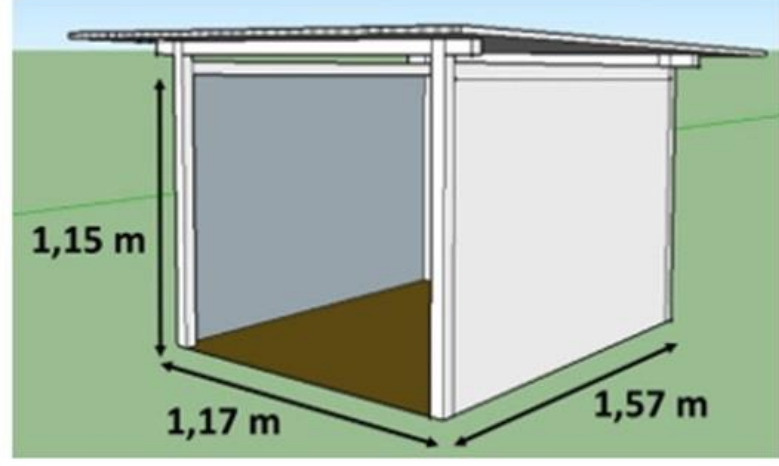

(b)

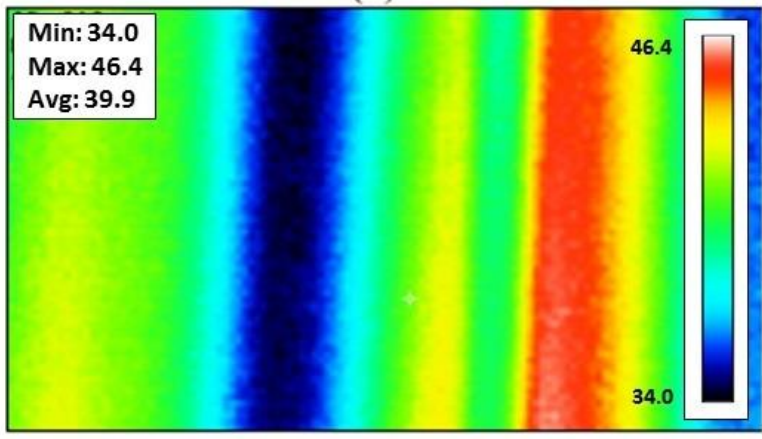

(d)

Figure 2. Characterization of treatments: design and dimensions of calf shelter with ceiling in blue B1 (a) and unlined calf shelter B2 (b). Thermographic image of the internal surfaces of B1 (c) and B2 (d): both pictures were taken in the same day/time/position.

Cravo et al. (2009) observed the same characteristics in studies with facilities for broilers. One hypothesis to be raised is that installations with hybrid particleboard ceiling of Pinus $s p$ and sugarcane bagasse have difficulty in dissipating the thermal energy, not being possible to affirm that the ceiling sheet was not efficient in reducing the heat flow into the shelter. As there were differences in surface temperatures in both treatments, it is possible to state that the heat flux may have been reduced in the installation with the ceiling (B1), but when the radiation emitted undergoes reflection in the soil and back to the ceiling, it is difficult to dissipate this heat into the environment. These conditions are consistent with the RTL values obtained in B1.

Associated with the thermal characteristics of the materials when allocated in a small facility, calf shelters are characterized as environments that are not totally isolated from the external environment. Instead, one of the facades (entrance) is fully open, being a free passage of air circulation and radiation, which brings with it climatic characteristics from the open area. In this way, the external temperature and relative 
humidity can influence in an intensive way the ambience conditions inside the individual shelters.

\section{Fuzzy system analysis}

Using the fuzzy system developed for this study, simulations were performed using input data from the experimental thermal comfort indices summarized in Table 1. Table 2 presents numerical and linguistic information generated by the fuzzy system (called "Comfort Situation"). The fuzzy system elaborated confirms the situation of alert during most part of the day times evaluated. Situation of comfort was seen only during the first time in the morning at 8:00 a.m. in treatment B2.

Table 2. Comfort situation: numerical and linguistic variables

\begin{tabular}{|c|c|c|c|c|}
\hline \multirow[t]{2}{*}{ Time } & \multicolumn{2}{|c|}{$\begin{array}{c}\text { Comfort } \\
\text { Situation } \\
\text { Numerical }\end{array}$} & \multicolumn{2}{|c|}{$\begin{array}{c}\text { Comfort Situation } \\
\text { Linguistic } \\
\end{array}$} \\
\hline & B1 & B2 & $\overline{\text { B1 }}$ & $\mathbf{B 2}$ \\
\hline 8 a.m. & 0.537 & 0.388 & $100 \%$ alert & $90 \%$ alert and $10 \%$ comfort \\
\hline 11 a.m. & 0.645 & 0.603 & $\begin{array}{c}75 \% \text { alert and } 25 \% \\
\text { emergency }\end{array}$ & $100 \%$ alert \\
\hline 2 p.m. & 0.735 & 0.702 & $\begin{array}{c}40 \% \text { alert and } 60 \% \\
\text { emergency }\end{array}$ & $\begin{array}{c}50 \% \text { alert and } 50 \% \\
\text { emergency }\end{array}$ \\
\hline 5 p.m. & 0.539 & 0.468 & $100 \%$ alert & $100 \%$ alert \\
\hline
\end{tabular}

As an example of the operation, Figure 3 presents the values entered in the fuzzy system (input variables) and its response (output variable) for 2:00 p.m. for shelter B1. The exit numerical value (Comfort Situation - 0.735) represents the variable in the fuzzy domain, defuzzifying, according to the pertinence function. This

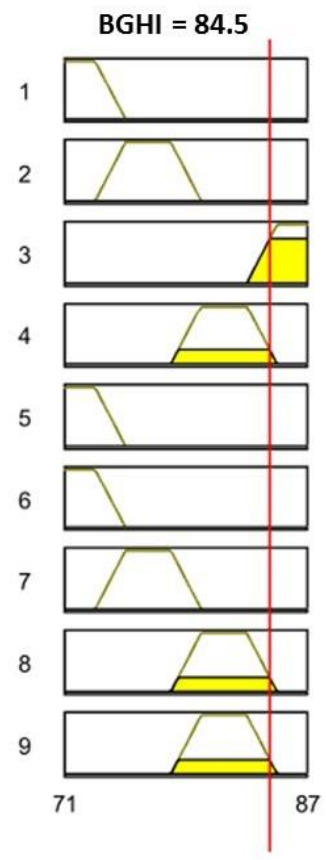

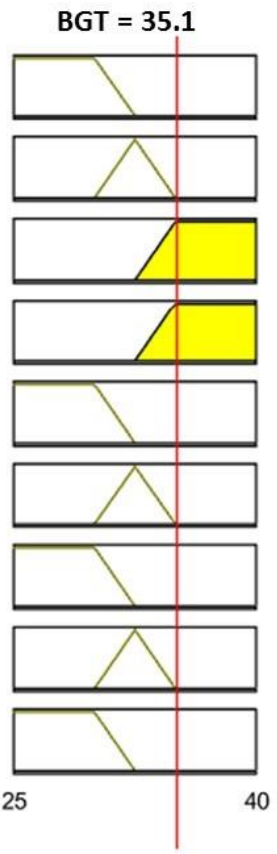

value represents $40 \%$ alert and $60 \%$ emergency in the linguistic variable. The results indicate that the proposed fuzzy model validates the experimental data and can be adopted to evaluate shelters for calves under the conditions of exposure and use.

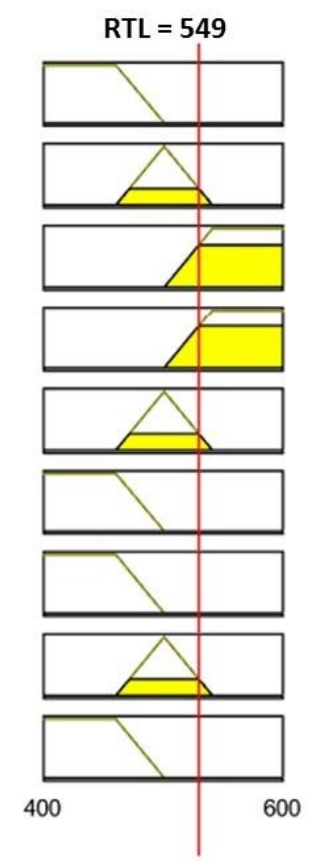

Figure 3. Example of the fuzzy analysis system simulation at 2:00 p.m. for treatment B1. 
Input (BGHI, BGT and RTL) and output (Comfort Situation) variables (numerical value of $0.735)$.

\section{CONCLUSIONS}

The thermal comfort indices evaluated in the period of the year with more critical temperatures - summer - for the study region indicated that the typical facilities (B2) and facilities with ceiling (B1) did not present an ideal comfort situation for the different times under evaluation. Although the ceiling insertion provided a reduction of the temperature close to the roof area and works wells as an insulating material (showed by

\section{AKNOWLEDGMENTS}

Authors recognize their gratitude to FAPESP (Fundação de Amparo à Pesquisa do Estado de São Paulo), process number 2012/13881-2, and CNPq (Conselho

\section{REFERENCES}

BAÊTA, F. C. Responses of lacting dairy cows to the combined effects of temperature, humidity, and wind velocity in the warm season. 1985. Thesis (PhD). Department of Agricultural Engineering, University of Missouri, Columbia, 1985.

BARBIRATO, G. H. A.; FIORELLI, J.; LINO, G.; CRAVO, J. C. M; BERTOLINI, M. S.; LAHR, F. A. R. Desempenho térmico de bezerreiros cobertos com telha de fibrocimento e forro ecológico de subprodutos agroindústrias associado a materiais isolantes. Revista Brasileira de Engenharia de Biossistemas, v. 9(3): 261267, 2015.

BARNABÉ, J. M. C; PANDORFI, H.; ALMEIDA, G. L. P.; GUISELINI, C.; JACOB, A. L. Conforto térmico e desempenho de bezerras Girolando alojadas em abrigos individuais com diferentes coberturas. Revista Brasileira de Engenharia Agrícola e Ambienta, v. 19(5): 481-488, 2015. thermographic images), no significant difference was detected in the thermal comfort indices evaluated. The model developed by fuzzy logic allows to compare the values of BGHI, BGT and RTL of the evaluated facilities and assign, through the values of these indices, a comfort situation in order to facilitate their study and analysis.

Nacional de Desenvolvimento Científico e Tecnológico), process number 800585/2016-0, for their financial support and scholarship.

BARNABÉ, J. M. C; PANDORFI, H.; ALMEIDA, G. L. P.; GUISELINI, C.; JACOB, A. L. Temperatura superficial de materiais utilizados para cobertura individual de bezerreiros. Revista Brasileira de Engenharia Agrícola e Ambiental, v. 18(5): 545-550, 2014.

BEDFORD, T.; WARNER, C.G. The globe temperature in studies of heating and ventilation. Pittsburg: Industrial Health Research Board, 1934. 7 p.

BOND, T. E.; KELLY, C. F. The globe thermometer in agricultural research. Agricultural Engineering, St. Joseph, MI. 1995. 10p.

CABRAL, M. R.; NAKANISHI, E. Y.; FIORELLI, J.; SAVASTANO JR, H. Avaliação do desempenho térmico de bezerreiros com eco-forro de partículas de madeira e fibra de sisal. Revista Brasileira de Engenharia de Biossistemas, v. 11(3): 
217-228, 2017.

CAMPOS, A. T.; KLOSOWSKI, E. S.; GASPARINO, E.; CAMPOS, A. T.; SANTOS, W. B. R. Análise térmica de abrigos indiviuais móveis e sombrite para bezerros. Acta Scientiarum. Animal Sciences, v. 27(1): 153-161, 2005.

CANEPPELE, F. L.; SERAPHIM, O. J.; GABRIEL FILHO, L. R. A.; CREMASCO, C. P.; SAVI, A. F. Gains obtained in hybrid systems of energy generation solar photovoltaic and wind power for rural electrification with the use of fuzzy logic controllers based. Agricultural Engineering, v. 2: 35-44, 2013.

CASTRO JUNIOR., S. L.; GARZON, N.; WILLIAMS, D.; GUESSO, F. L.; SAVASTANO JUNIOR, H.; ROSSIGNOLO, J. A.; FIORELLI, J. Particleboards with Agricultural Wastes: Sugar Cane Bagasse and Reforestation Wood. Key Engineering Materials, v. 600: 667-676, 2014.

CRAVO, J. C. M.; FIORELLI, J.; LAHR, F. A. R.; FONSECA, R.; CRUZ, V. C. Evaluation of recycled tiles and OSB ceiling materials in closed broiler house prototypes. Revista Brasileira Ciência Avícola, v. 11(4): 219-224, 2009.

CURTIS, S. E. Environmental management in animal agriculture. AMES: The lowa State University Press, 1983. $409 \mathrm{p}$.

DA SILVA, K. C. P.; CAMPOS, A. T.; YANAGI JUNIOR, T.; CECCHIN, D.; LOURENÇONI, D.; FERREIRA, J. C. Reaproveitamento de resíduos de embalagens Tetra Pak- ${ }^{\circledR}$ em coberturas.

Revista Brasileira de Engenharia Agrícola e Ambiental, v. 19(1): 58-63, 2015.

DIKMEN, S.; HANSEN, P. J. Is the temperature-humidity index the best indicator of heat stress in lactating dairy cows in a subtropical environment? Journal of Dairy Science, v. 92: 109-116, 2009.

FERREIRA, R. A. Maior produção com melhor ambiente para aves, suínos e bovinos. Viçosa: Aprenda Fácil, 2005.

FURTADO, D. A.; AZEVEDO, P.V.; TINOCO, I. F. F. Analise do Comporto térmico em galpões avícolas com diferentes sistemas de acondicionamento. Revista Brasileira de Engenharia Agrícola e Ambiental, v.7(3): 559-564, 2003.

GABRIEL FILHO, L. R. A.; CREMASCO, C. P.; PUTTI, F. F.; CHACUR, M. G. M. Application of fuzzy logic for the evaluation of livestock slaughtering. Engenharia Agrícola, v. 31(4): 813-825, 2011.

KAWABATA, C. Y.; CASTRO, R. C.; SAVASTANO JUNIOR, $H$. Índices de conforto térmico e respostas fisiológicas de bezerros da raça holandesa em bezerreiros individuais com diferentes coberturas. Engenharia Agrícola, v. 25(3): 598-607, 2005.

SHAW, I. S.; SIMÕES, M. G. Controle e modelagem Fuzzy. 2. ed. São Paulo. 2007. $180 \mathrm{p}$.

VASCONCELOS, A. M.; MORAES, D. A. E. F.; OLIVO, C. J.; FARIAS, D. A.; SAENZ, E. A. C.; LANDIM, A. V.; GOMES, T. C. L.; ROGÉRIO, M. C. P.; GOÉS, K. L. S.; NASCIMENTO, J. R.; OLIVEIRA JÚNIOR, A. A. Desempenho de bezerros leiteiros submetidos a diferentes dietas líquidas e instalações durante $o$ período hibernal. Acta Veterinaria Brasilica, v. 3(4): 163-171, 2009.

ZADEH, L. Fuzzy Sets. Information and Control. Berkeley, v.8, n.1, p.338-353, 1965. 